African Crop Science Journal by African Crop Science Society is licensed under a Creative Commons Attribution 3.0 Uganda License. Based on a work at www.ajol.info/ and www.bioline.org.br/cs DOI: https://dx.doi.org/10.4314/acsj.v27i3.8

\title{
CORRELATIONS AND PATH ANALYSIS OF YIELD TRAITS IN SORGHUM GROWN IN SOUTHWESTERN HIGHLANDS OF UGANDA
}

\author{
R. AKATWIJUKA, P.R. RUBAIHAYO and T.L. ODONG \\ College of Agricultural and Environmental Sciences, School of Agricultural Sciences, \\ Makerere University, P. O. Box 7062, Kampala, Uganda \\ Corresponding author: akarogerz@yahoo.co.uk
}

(Received 31 January 2019; accepted 24 July 2019)

\begin{abstract}
The study of relationships among traits is essential for assessing the feasibility of joint selection for two or more traits. Path coefficient analysis partitions correlation coefficient into direct and indirect contributions of various traits towards dependent variable, thus guiding effective selection. A study was conducted to determine the correlation and path coefficients for sorghum (Sorghum bicolor $\mathrm{L}$. Moench) grain yield and quantitative traits among 47 sorghum cultivars collected from southwestern highlands of Uganda. The study was conducted at Kachwekano Research Farm in Kabale District in southwestern Uganda, at an altitude of 2,223 metres above sea level, during the two successive sorghum growing seasons of December 2014 to August 2015 and December 2015 to August 2016. Correlations revealed strong significant trait associations $(\mathrm{P}<0.001)$ for grain yield with panicle weight $(\mathrm{r}=0.938)$, and moderately strong relationships with panicle width $(\mathrm{r}=0.619)$, stem girth $(\mathrm{r}=0.674)$, and leaf width ( $\mathrm{r}=0.576)$. Grain yield revealed a non-significant negative correlation with days to $50 \%$ flowering $(\mathrm{r}=-0.011)$. Regression analysis revealed that panicle weight and plant height had the highest direct effect on grain yield of 1.085 and 0.2097 , respectively. Path coefficient analysis revealed that stem girth $(0.814)$, leaf width $(0.74901)$ and panicle width $(0.713)$ had the highest indirect contributions to grain yield. The residual effect was low $(\mathrm{R}=0.11)$, with high adjusted $\mathrm{R}^{2}$ value $(0.89)$.
\end{abstract}

Key Words: Path coefficients, regression, Sorghum bicolor

\section{RÉSUMÉ}

L'étude des relations entre les traits est essentielle pour évaluer la faisabilité d'une sélection conjointe de deux traits ou plus. L'analyse du coefficient de consanguinité partage le coefficient de corrélation en contributions directes et indirectes de divers traits à la variable dépendante, guidant ainsi la sélection effective. Une étude a été faite pour déterminer les coefficients de corrélation et de consanguinité pour le rendement en grain de sorgho (Sorghum bicolor L. Moench) et les caractères quantitatifs parmi 47 cultivars de sorgho collectés dans les hautes altitudes du sud-ouest de l'Ouganda. L'étude a été faite à la ferme de recherche Kachwekano, dans le district de Kabale, dans le sud-ouest de l'Ouganda, à 2223 mètres d'altitude, au cours des deux saisons de culture de sorgho successives 
de Décembre 2014 à Août 2015 et de Décembre 2015 à Août 2016. Les corrélations ont révélé un trait associations $(\mathrm{P}<0,001)$ pour le rendement en grain avec le poids de la panicule $(\mathrm{r}=0,938)$ et des relations modérément fortes avec la largeur de la panicule $(\mathrm{r}=0,619)$, la circonférence de la tige $(\mathrm{r}=$ $0,674)$ et la largeur de la feuille $(\mathrm{r}=0,576)$. Le rendement en grains a révélé une corrélation négative non significative avec la floraison en jours à $50 \%(\mathrm{r}=-0,011)$. Une analyse de régression a révélé que le poids de la panicule et la hauteur de la plante avaient l'effet direct le plus élevé sur le rendement en grain, à savoir 1,085 et 0,2097, respectivement. L'analyse du coefficient de consanguinité a révélé que la circonférence de la tige $(0,814)$, la largeur des feuilles $(0,74901)$ et la largeur de la panicule $(0,713)$ avaient les contributions indirectes les plus élevées au rendement en grain. L'effet résiduel était faible ( $R=0,11)$, avec une valeur de $R^{2}$ ajustée élevée $(0,89)$.

Mots Clés: Coefficients de consanguinité, régression, Sorghum bicolor

\section{INTRODUCTION}

Sorghum (Sorghum bicolor L. Moench) is a staple food and commercial crop for over $95 \%$ of the households in the highlands of southwestern Uganda (Nabimba et al., 2005). Different sorghum cultivars exist in this region, with yields reportedly poor at $17 \%$ of its yield potential due to use of a combination of inferior genotypes and abiotic and biotic factors (Nabimba et al. 2005). Genetic improvement of crop plants by plant breeding has made a major contribution to food production throughout the world, through production of high yielding cultivars that can tolerate both abiotic and biotic stresses (Fehr, 1987).

Yield is a complex quantitative trait with low heritability; and depends upon several other components with varying heritabilities. These components are in turn interrelated, which influences their relationships with yield. Simple correlations do not give insight into the true biological relationships of these traits with yield. Path coefficient analysis, described by Dewey and Lu (1959), allows for partitioning of correlation coefficient, into direct and indirect contributions of various traits towards dependent variable; and thus it helps in assessing the cause-effect relationships, as well as effective selection.

Studies of correlation and path analysis have been reported in sorghum, with contradictory results (Girish et al., 2016; Warkad et al., 2010); but there are no such reported studies in relation to sorghum cultivars in the highlands of southwestern Uganda. A study was, therefore, undertaken to elucidate the correlations of grain yield and yield contributing traits among sorghum cultivars in this region, to help the selection of desirable genotypes for the high seed yielding trait.

\section{MATERIALS AND METHODS}

The study was conducted in the highland agroecological zone of southwestern Uganda, which lies at latitude 0115 37S, 2958 43E, and altitudes ranging from 1,500 to $4,000 \mathrm{~m}$ above sea level. The zone covers a total land area of approximately $5,180 \mathrm{Km}^{2}$, excluding open water, with a mean annual rainfall of $1,400 \mathrm{~mm}$ and mean annual temperature of 15 ${ }^{\circ} \mathrm{C}$ (NEMA-Uganda, 2009)

Study materials and management. The study materials consisted of 47 sorghum cultivars collected from farmers in the zone, during the sorghum harvesting months of July and August 2013. Each selected farmer, based on experience in growing sorghum, was asked to provide two mature panicles of each named sorghum in his/her field and the source of seed and time the farmer had been engaged in growing the cultivars. The collected cultivars were evaluated at Kachwekano Zonal Agricultural Research and Development Institute (KAZARDI) farm, at an altitude of 2,223 $\mathrm{m}$ above sea level, during the two 
successive sorghum growing seasons of December 2014 to August 2015 and December 2015 to August 2016. Planting was done on $28^{\text {th }}$ January 2015 in the first growing season and on $28^{\text {th }}$ January 2016 in the second growing season in a randomised complete block design, on 2.4 by $1.4 \mathrm{~m}$ plots and between plots of $1.5 \mathrm{~m}$, with inter-row spacing of $60 \mathrm{~cm}$ and intra-row spacing of $20 \mathrm{~cm}$ at a depth of 10 $\mathrm{cm}$. Two seeds were sown in each hole. Thinning, was removing one weak seedling manually at first weeding. Manual weeding was done three times, during the crops' vegetative stages (at three, seven and fourteen weeks) after planting.

Data collection. Quantitative data were recorded on days to $50 \%$ flowering, plant height, number of leaves, length and width of third leaf from top of each sampled plant; stem girth, exsertion length, peduncle length, panicle length and width, panicle weight, and 100 -seed weight. Plant height was taken from the base of the plant to the tip of the head at physiological maturity. Number of leaves was determined by counting all leaves from first to the flag leaf. Leaf length data were taken from the base to tip of the leaf, leaf width on the widest part of the same leaf, exertion length from ligule of flag leaf to base of panicle; and peduncle length from the last node of the stalk to the base of the panicle. Panicle length was recorded by measuring each panicle from its base to its tip, with its width measurements recorded at the widest part in natural position. Panicle and 100-seed weight were taken after harvest, and sun-dried at moisture content of approximately $12 \%$. Panicle weight was used to determine yield per hectare, by multiplying the average grain weight per panicle with the total number of plants in a hectare (Fernandez et al., 2012), considering germination failure and premature plant death.

Data analysis. Since the units of measurements for different traits were not the same, mean scores for the various traits were standardised (Akintunde, 2012) using Microsoft Excel 2013 computer programme. Data standardisation followed the expression $\mathrm{x}=(\mathrm{x}-\mathrm{m}) / \mathrm{sd}$, where $\mathrm{x}=$ score, $\mathrm{m}=$ group mean, $s d=$ group standard deviation. This was followed by correlation, regression and path analyses using Microsoft Excel 2013 computer programme as described by Akintunde (2012). Grain yield was considered a dependent variable, and the rest of the traits were considered as independent variables (Akintunde, 2012). Statistical significance of correlation coefficients for different trait associations were determined using GenStat ( $14^{\text {th }}$ edition) computer software.

\section{RESULTS AND DISCUSSION}

The results of correlation analysis are presented in Table 1. There were high positive and significant $(\mathrm{p}<0.001)$ correlation between grain yield and panicle weight $(\mathrm{r}=0.938)$, stem girth $(r=0.674)$, panicle width $(r=0.619)$ leaf width $(r=0.576)$ and leaf length $(r=0.429)$.

The high positive correlation between yield and yield contributing components, suggested that these traits can be simultaneously selected for high yielding varieties; and are dependable indicators for high yielding varieties. The strong association of yield with leaf width and length, suggested a strong photosynthetic apparatus that would be important for grain filling, hence increasing yield. Previous studies in sorghum have also reported a high positive correlation between grain yield and various yield related traits (Ezeaku and Mohammed, 2006; DossouAminon et al., 2015).

Grain yield revealed a negative nonsignificant correlation with days to $50 \%$ flowering $(r=-0.011)$, suggesting that this variable had no significant effect on grain yield. This meant that variations in the days to $50 \%$ flowering were not large enough to cause significant differences in grain yield.

Results of regression analysis of yield against yield traits are presented in Table 2 . The high values of adjusted R Square (0.89), 
TABLE 1. Phenotypic correlation matrix of sorghum characteristics in the study of yield and yield contributing traits in sorghum grown in southwestern highlands of Uganda

\begin{tabular}{|c|c|c|c|c|c|c|c|c|c|c|c|c|c|}
\hline & $\begin{array}{l}\text { YD } \\
\left(\mathrm{t} \mathrm{ha}^{-1}\right)\end{array}$ & $\begin{array}{l}\mathrm{D} \text { to } \\
50 \% \mathrm{~F}\end{array}$ & $\begin{array}{l}\mathrm{PH} \\
(\mathrm{cm})\end{array}$ & $\begin{array}{l}\mathrm{LW} \\
(\mathrm{cm})\end{array}$ & $\begin{array}{l}\text { SG } \\
(\mathrm{cm})\end{array}$ & $\begin{array}{l}\mathrm{LL} \\
(\mathrm{cm})\end{array}$ & NL & $\begin{array}{l}\text { PNL } \\
(\mathrm{cm})\end{array}$ & $\begin{array}{r}\text { PNW } \\
(\mathrm{cm})\end{array}$ & $\begin{array}{l}\text { EXL } \\
(\mathrm{cm})\end{array}$ & $\begin{array}{cc}\text { PDL } & \text { P } \\
(\mathrm{cm}) & \end{array}$ & $\begin{array}{l}\text { PANWT } \\
\text { (g) }\end{array}$ & $\begin{array}{c}100-S \\
(\mathrm{~g})\end{array}$ \\
\hline $\mathrm{YD}\left(\mathrm{tha}^{-1}\right)$ & 1 & & & & & & & & & & & & \\
\hline $\mathrm{D}$ to $50 \% \mathrm{~F}$ & -0.011 & 1 & & & & & & & & & & & \\
\hline $\mathrm{PH}(\mathrm{cm})$ & 0.165 & 0.1639 & 1 & & & & & & & & & & \\
\hline $\mathrm{LW}(\mathrm{cm})$ & $0.576 * *$ & -0.054 & -0.122 & 1 & & & & & & & & & \\
\hline $\mathrm{SG}(\mathrm{cm})$ & $0.674 * *$ & 0.0012 & -0.019 & $0.726^{* *}$ & 1 & & & & & & & & \\
\hline $\mathrm{LL}(\mathrm{cm})$ & $0.429 * *$ & -0.067 & 0.312 & $0.558 * *$ & $0.517 * *$ & 1 & & & & & & & \\
\hline NL & 0.429 & 0.1617 & $0.567 * *$ & 0.295 & 0.424 & 0.453 & 1 & & & & & & \\
\hline $\mathrm{PNL}(\mathrm{cm})$ & 0.38 & -0.137 & 0.031 & 0.25 & 0.358 & 0.356 & 0.085 & 1 & & & & & \\
\hline PNW (cm) & $0.619 * *$ & 0.1878 & -0.185 & $0.582 * *$ & $0.605^{* *}$ & 0.278 & 0.233 & 0.327 & 1 & & & & \\
\hline EXL (cm) & $-0.624 * *$ & 0.1054 & -0.059 & $-0.754 * *$ & $-0.74 * *$ & $-0.69 * *$ & $-0.57 * *$ & -0.35 & $-0.52 * *$ & 1 & & & \\
\hline PDL (cm) & -0.488 & -0.143 & 0.242 & $-0.668 * *$ & -0.64 & -0.35 & -0.38 & 0.063 & $-0.58 * *$ & $0.763 * *$ & 1 & & \\
\hline PANWT (g) & $0.938 * *$ & -0.033 & 0.048 & $0.69 * *$ & $0.75^{* *}$ & $0.519 * *$ & 0.45 & 0.388 & $0.657 * *$ & $-0.74 * *$ & $-0.62 * *$ & 1 & \\
\hline $100-S(g)$ & 0.393 & -0.159 & 0.308 & 0.067 & 0.103 & 0.422 & 0.165 & 0.317 & 0.079 & -0.18 & 0.118 & 0.41 & 1 \\
\hline
\end{tabular}

D to $50 \% \mathrm{~F}=$ Days to $50 \%$ flowering, $\mathrm{PH}=$ Plant height, $\mathrm{LW}=$ leaf width, $\mathrm{SG}=$ stem girth, $\mathrm{LL}=$ leaf length, $\mathrm{NL}=$ number of leaves, $\mathrm{PNL}=$ panicle length, $\mathrm{PNW}=$ panicle width, $\mathrm{EXL}=$ exertion length, $\mathrm{PDL}=$ peduncle length, $\mathrm{PANWT}=$ panicle weight and $100-\mathrm{S}=$ one hundred seed weight 
TABLE 2. Regression of sorghum yield and yield contributing traits

\begin{tabular}{ll}
\hline Multiple R & 0.96 \\
R Square & 0.92 \\
Adjusted R Square & 0.89 \\
Standard Error & 0.33 \\
Observations & 47.00
\end{tabular}

ANOVA

\begin{tabular}{|c|c|c|c|c|c|c|}
\hline & df & SS & MS & $\mathrm{F}$ & Significance F & \\
\hline Regression & 12.00 & 42.37 & 3.53 & 33.10 & $3.1484 \mathrm{E}^{-15}$ & \\
\hline Residual & 34.00 & 3.63 & 0.11 & & & \\
\hline \multirow[t]{2}{*}{ Total } & 46.00 & 46.00 & & & & \\
\hline & Coefficients & $\begin{array}{l}\text { Standard } \\
\text { Error }\end{array}$ & t Stat & P-value & Lower $95 \%$ & $\begin{array}{l}\text { Upper } \\
95 \%\end{array}$ \\
\hline Intercept & 0.54 & 0.05 & 11.24 & $5.428 \mathrm{E}^{-13}$ & 0.44 & 0.63 \\
\hline $\mathrm{D}$ to $50 \% \mathrm{~F}$ & -0.03 & 0.06 & -0.45 & 0.65 & -0.15 & 0.09 \\
\hline $\mathrm{PH}(\mathrm{cm})$ & 0.21 & 0.08 & 2.52 & 0.02 & 0.04 & 0.38 \\
\hline LW (cm) & -0.06 & 0.09 & -0.67 & 0.51 & -0.24 & 0.12 \\
\hline $\mathrm{SG}(\mathrm{cm})$ & 0.01 & 0.09 & 0.14 & 0.89 & -0.17 & 0.19 \\
\hline $\mathrm{LL}(\mathrm{cm})$ & $-(0.07$ & 0.08 & -0.87 & 0.39 & -0.24 & 0.10 \\
\hline $\mathrm{NL}$ & -0.12 & 0.11 & -1.03 & 0.31 & -0.35 & 0.11 \\
\hline $\mathrm{PNL}(\mathrm{cm})$ & 0.00 & 0.08 & 0.06 & 0.95 & -0.15 & 0.16 \\
\hline PNW $(\mathrm{cm})$ & 0.08 & 0.08 & 1.05 & 0.30 & -0.07 & 0.24 \\
\hline $\operatorname{EXL}(\mathrm{cm})$ & 0.05 & 0.15 & 0.31 & 0.76 & -0.27 & 0.36 \\
\hline $\operatorname{PDL}(\mathrm{cm})$ & 0.06 & 0.14 & 0.42 & 0.68 & -0.22 & 0.34 \\
\hline PANWT (g) & 1.09 & 0.11 & 9.82 & 0.00 & 0.86 & 1.31 \\
\hline $100-S(g)$ & -0.08 & 0.07 & -1.11 & 0.28 & -0.22 & 0.07 \\
\hline
\end{tabular}

$\mathrm{df}=$ degrees of freedom, $\mathrm{SS}=$ sums of squares, $\mathrm{MS}=$ means of squares

low standard error value (0.33) and low residual effect $(\mathrm{R}=0.11)$ indicated that a great deal of variability of grain yield was explained by the variables in the study.

Similar results of low $\mathrm{R}$ value in sorghum were reported by Ezeaku and Mohammed (2006). On the other hand, Khandelwal et al. (2015) reported higher $\mathrm{R}$-values $(\mathrm{R}=0.49)$. This suggested that in some instances, variability in grain yield could be attributed to variables other than those in the study. The Pvalue for the intercept was significantly less than alpha $(\mathrm{P}<0.05)$, implying that the slope or intercept was significantly different from zero; and the null hypothesis of no effect of various traits on yield was rejected. It also meant that the regression model was significantly a good fit (Zaiontz, 2015). The $\mathrm{P}$ - values for all the coefficients; with the exception of plant height and panicle weight, were greater than 0.05 ; suggesting that only these two traits significantly contributed to the observed variation in grain yield. Panicle weight had the largest value of correlation coefficient $(r=1.09)$ on yield, suggesting targeting increased panicle weight in selection of grain yield.

Results of correlation coefficients and direct effects of different traits, regressed with grain yield are presented in Table 3 . Panicle 
TABLE 3. Correlation coefficients and direct effects of traits to sorghum grain yield in a study of grain yield and yield contributing traits

\begin{tabular}{lcc}
\hline Causal traits & Correlation coefficients & Direct effects \\
\hline Days to 50\% flowering & -0.01 & -0.03 \\
Plant height $(\mathrm{cm})$ & 0.17 & 0.21 \\
Leaf width $(\mathrm{cm})$ & 0.58 & -0.06 \\
Stem girth $(\mathrm{cm})$ & 0.67 & 0.01 \\
Leaf length $(\mathrm{cm})$ & 0.43 & -0.07 \\
Number of leaves & 0.43 & -0.12 \\
Panicle length $(\mathrm{cm})$ & 0.38 & 0.00 \\
Panicle width $(\mathrm{cm})$ & 0.62 & 0.08 \\
Exsertion length $(\mathrm{cm})$ & -0.62 & 0.05 \\
Peduncle length $(\mathrm{cm})$ & -0.49 & 0.06 \\
Panicle weight $(\mathrm{g})$ & 0.94 & 1.09 \\
100-seed weight $(\mathrm{g})$ & 0.39 & -0.08
\end{tabular}

weight had the highest direct effect on grain yield $(\mathrm{r}=1.09)$, implying that panicle weight could be relied on for direct selection of high yielding plants since it scored highly both on correlation matrix $(\mathrm{r}=0.94)$ and direct effects (1.09).

The relatively high direct contribution of plant height to yield $(0.21)$, but with low correlation coefficient $(0.17)$, suggests that plant height indirectly contributed to grain yield. Doggett (1988) reported that the height of the plant influences the number of nodes produced, which equates with the number of leaves produced. The larger number of leaves, if properly illuminated, provides more photosynthetic capacity, and hence increased yield. The correlation coefficients between yield and panicle weight $(r=0.94)$, and yield and plant height $(r=0.17)$ were close to their corresponding direct effects (1.09 and 0.21, respectively), implying that the observed correlation coefficient, explained the true relationships (Akintunde, 2012). Leaf width, leaf length, number of leaves and 100-seed weight whose correlation coefficient values were positive, but with negligible to negative direct effects, indicated that the indirect effects caused the observed correlation.
Results of path coefficient analysis showing direct and indirect effects of traits on grain yield are presented in Table 4. Panicle width (0.713), 100-sed weight (0.445) and panicle length (0.421) had the highest indirect contribution to grain yield through panicle weight, suggesting the importance of these traits to both panicle weight and grain yields; and the need to consider them simultaneously when selecting for yield improvement in sorghum. Stem girth (0.814), leaf width (0.749), leaf length (0.563) and number of leaves (0.489) exhibited the highest indirect contributions to grain yield via panicle weight, among the vegetative traits, suggesting the need to consider them simultaneously when selecting for high yielding sorghum cultivars.

\section{ACKNOWLEDGEMENT}

This study was funded by Carnegie of New York and EU-supported Outreach project (FED/2009/217080), through Regional Universities Forum for Capacity Building in Agriculture (RUFORUM). Kachwekano Zonal Agricultural Research and Development Institute (KAZARDI) provided the experimental plots. 


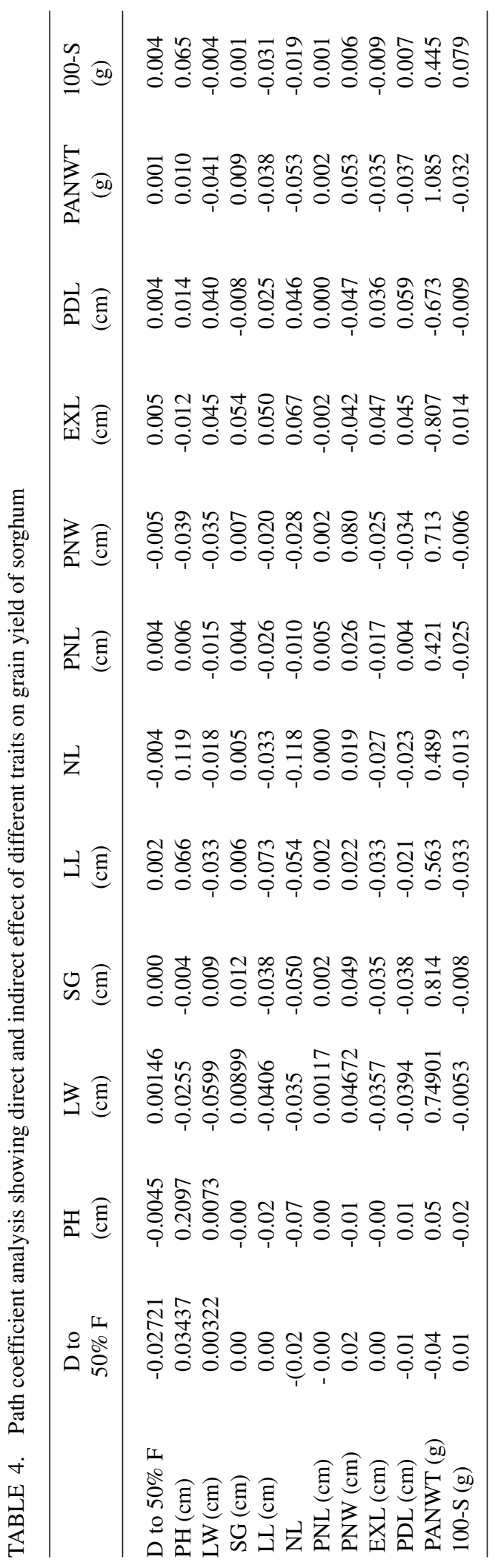

\section{REFERENCES}

Akintunde, A. 2012. Path analysis step by step using Excel. Journal of Technical Science and Technologies 1(1):9-15.

Dewey, D.R. and Lu, K.H. 1959. A correlation and path coefficient analysis of components of crested wheatgrass seed production. Agronomy Journal 51: 515-518.

Doggett, H. 1988. Sorghum. $2^{\text {nd }}$ ed. Tropical Agricultural Series. Longman Scientific, Essex, UK.

Dossou-Aminon, I., Yêyinou, L., Adjatin, A. and Ewédjè, E.B.K. 2015. Genetic divergence in Northern Benin sorghum (Sorghum bicolor L. Moench) landraces as revealed by agromorphological traits and selection of candidate genotypes. Scientific World Journal 916476

Ezeaku, I.E. and Mohammed, S.G. 2006. Character Association and Path Analysis in Grain Sorghum. African Journal of Biotechnology 5(14):1337-1340.

Fehr, W.R. 1987. Principles of cultivar development, Volume 1: Theory and Techniques. Macmillan Publishing Company, New York, USA.

Fernandez, C.J., Dan, D., Fromme, D.D. and Grichar, J.W. 2012. Grain sorghum response to row spacing and plant populations in the Texas Coastal Bend Region. International Journal of Agronomy, 238634. Hindawi Publishing Corporation

Gerik, T., Bean, B. and Vanderlip, R. 2003. Sorghum growth and development, Texas Cooperative Extension Service University of Arkansas 2301 S. University, P. O. Box 391 Little Rock, Arkansas 72203. Arkansas Printing Services.

Girish, G., Kiran, S.B., Lokesh, R., Kulkarni, V., Rachappa, V., Yogesh, L.N. and Talwar, A.M. 2016. Character association and path analysis in advanced breeding lines of Rabi sorghum [Sorghum bicolor (L.) Moench]. Journal of Applied and Natural Sciences 8(1): 35- 39 
Khandelwal, V., Shukla, M., Nathawat, V.S. National Environment Management Authority and Jodha, B.S. 2015. Correlation and path coefficient analysis for agronomical traits in sorghum [Sorghum bicolor (L.) Moench] under shallow saline soil condition in arid region. Electron Journal of Plant Breeding 6(4):1143-1149,

Nabimba, F., Kashaija, I.N., Wagoire, W.W., Bamwerinde, W.M., Kakuhenzire, R., Kikafunda, J. and Kamanyi, J. 2005. Significance of sorghum in the south western highlands agro-ecological zone of Uganda. African Crop Science Journal 7: 971-978.

(NEMA) - Uganda. 2009. Atlas of our changing environment. Ministry of Water and Environment, P. O. Box 22255, Kampala, Uganda.

Warkad, Y.N., Tidke, R.T., Maske, N.M., Kharde, A.V. and Potdukhe, N.R. 2010. Character association and path analysis in sorghum (Sorghum bicolor L. Moench). International Journal of Agricultural Sciences 1(6):100-104.

Zaiontz, C. 2015. Testing the significance of the slope of regression line. Real Statistics Resource Pack Software. Release 4.3. www.real-statistics.com 